\title{
A fogszabályozó bracketek ragasztásának módszerei, összehasonlításuk a bracketleválási ráta alapján
}

\author{
SVIDRÓ ESZTER*, DR. IVÁNYI DÓRA**, DR. HORVÁTH JÁNOS**
}

\begin{abstract}
Fogszabályozó kezelés során sok esetben ív rögzítésére szolgáló bracketeket ragasztanak a fogzománcra. A keletkező rendszernek ellen kell állnia az egész kezelési idő alatt az elmozdító erőknek (okklúzió, rágóerő, ív ereje), és amikor a bracket eltávolításra kerül, lehetőleg sértetlen zománcfelületet kell hátrahagynia maga után. A bracket-ragasztás minőségét a választott technika határozza meg. Célunk a napjainkban használt különböző ragasztási technikák összehasonlító elemzése a bracket-leválási ráta alapján a következő szempontok szerint: direkt-indirekt módszer, használt bracket ragasztóanyagok és a fogzománc előkészítése. A szakirodalmi adatok, vizsgálatok felkutatására a PubMed és a Google Scholar keresőmotorokat használtuk. Az összehasonlítás kiegészítéseként a Fogászati és Szájsebészeti Oktató Intézetben fogszabályozó kezelésben résztvevő páciensekről gyújtöttünk adatokat (direkt technika, kompozit alapú ragasztó, többlépéses zománc kondicionálás). A felhasznált bracketek megrendelési és utánrendelési számai alapján a leválási ráta $4,1 \%$, ami a szakirodalom által elfogadott $10 \%$ alatti értéken belül helyezkedik el $[24,6]$.

Összességében a direkt és indirekt bracket-ragasztást összehasonlítva a feldolgozott források alapján nem találtunk szignifikáns eltérést a kétféle módszer között. Ragasztóanyagok tekintetében a legnagyobb kötőerők a kompozit rezinek használatakor keletkeznek. A fogzománc hagyományos, többlépéses kondicionálása a legtöbb vizsgálat szerint kisebb leválási rátát eredményez, mint a self-etch rendszerek használata.
\end{abstract}

Kulcsszavak: fogszabályozás, bracket, bracket ragasztóanyag, leválási ráta

\section{Bevezetés}

A fogszabályozó kezelés számos esetben rögzített készülékkel történik. Ilyenkor az ívek rugalmas alakváltozása következtében fellépő erőket fogszabályozó bracketek közvetítik a fogakra. Funkciójuk betöltéséhez valamilyen módon tartósan kell rögzülniük a fogfelszínhez, ami ragasztóanyag közbeiktatásával történik.

A fogszabályozó bracketek ragasztási technikáit két nagy csoportba oszthatjuk: direkt és indirekt módszerre. Az első esetben minden bracketet egyesével a fogszabályozó orvos ragaszt fel, a másodiknál pedig több bracketet egyszerre rögzítenek egy egyéni átvivősablon segítségével. In vitro vizsgálatok extrahált premoláris fogakon végzett kísérletei nem találtak szignifikáns különbséget nyírószilárdsági értékek tekintetében a kettő között [37]. A bracketek pozicionálását tekintve több vizsgálat leírta, hogy az indirekt ragasztás, ha nem is minden faktor esetén szignifikánsan, de jobb és pontosabb volt a magasságot, a mesiodistális pozíciót és az angulációt figyelembe véve [14, 26]. Emellett jelentősen lerövidíti a ragasztáshoz szükséges időtartamot. A direkt technika mellett szól, hogy a ragasztófelesleget könnyebben el tudták távolítani mielött meg- kötött, illetve a ragasztó minden esetben maximálisan kitöltötte a brackettalp és a fog közötti helyet. A munkaterület az egész múvelet alatt jól belátható volt és az esetleges okklúziós interferenciákat közvetlenül lehetett ellenőrizni [38].

Sokszor a választott technika meghatározza a használt anyagokat is. Jelenleg anyagtanilag négy kategóriába sorolhatók a bracket-ragasztók: kompozitok, konvencionális üvegionomer cementek, rezin-módosított üvegionomer cementek és kompomerek.

A kompozit alapú ragasztóanyagok összetétele sokat fejlődött azóta, hogy 50 éve megtörtént piaci bevezetésük [8, 33]. Közös bennük, hogy mindegyik alapvetően egy polimer mátrixból áll, amit töltőanyag erősít meg, a kettőt egy szilán kötésú rendszer tartja össze. A kompozit polimerizációját, illetve ennek modulációját további hozzáadott adalékanyagok biztosítják [8]. Az anyag monomerjei szabadgyökök által kiváltott addíciós reakció segítségével polimerizálódnak. A szabadgyökök keletkezése szerint megkülönböztetünk belső (kémiai) vagy külső (fény, hő) aktivációt. A kompozit alapú ragasztók applikációja érzékeny folyamat, a zománc savazása után legtöbbször teljesen száraz felszínt kell biztosítani a primer használatánál és utána a ragasztó felvitelénél a kötéshez [7]. 
Az üvegionomer cementek kifejlesztésénél elsődleges cél a fogakra kerülő gyűrűk ragasztására alkalmas anyag kidolgozása volt. Az első üvegionomerek fizikai tulajdonságai nem voltak túlságosan kedvezőek a direkt bracket-ragasztáshoz [22]. A továbbfejlesztett, modern fajták már jobb fizikai karakterisztikát mutatnak. Manapság az üvegionomer cementek polialkénsav és ionokat leadó szilikátüveg keverékéből tevődnek öszsze $[16,17,22]$. Az anyag egyik legnagyobb előnye, hogy képes fluoridot felvenni a környezetéből (például fogkrémből), ezután hosszútávon raktárként működik és legalább 12 hónapig tud fluoridot leadni a zománcfelszínnek és környékének [28]. Az üvegionomerrel történő első direkt bracket-ragasztást White írta le 1986-ban. A zománc savazása nélküli ragasztással kapcsolatos biztató eredmények miatt kezdtek el kísérletezni ezzel az anyagcsoporttal. Az eredeti céllal ellentétben azonban továbbra is szükséges a zománc savazása a klinikai használathoz megfelelő nagyságű kötőerők kifejlődéséhez [22, 27].

Az üvegionomer cementek számos elönyös tulajdonságuk mellett nem tudtak a kompozit ragasztóanyagokhoz mérhető kötőerőket produkálni. Azért, hogy növeljék a kötés erejét, rezint kevertek az üvegionomerhez és 1995-ben megjelentek a rezin-módosított üvegionomerek (resin modified glass ionomer cement, RMGIC). A kötőerők nagysága azonban még mindig nem éri el a kompozitokét, de ez nem is feltétlenül célja a gyártóknak, hiszen megfelelően „alacsony” kötőerők mellett a bracketeket könnyebb eltávolítani. Elméletileg nem is szükséges kondicionálás a zománchoz kémiailag kötő RMGIC használatánál a mikromechanikai retenció eléréséhez, mégis a klinikumban a kötőerők növelése érdekében általában 10\%-os poliakrilsavas savazást alkalmaznak a ragasztás előtt [3, 16, 28, 36].

A kompomereket (polyacid-modified composite resins) az 1990-es évek elején teljesen új kategóriaként mutatták be a fogászati anyagok között, azonban igazából az eddig is használt és bevált anyagok „összekeveréséből" keletkeztek. A kompomer elnevezést két anyagnév kombinációja adja: „komp” a kompozitból és „omer” az üvegionomerből. A hagyományos kompozit rezinek esztétikáját és az üvegionomer cementek fluoridleadását és adhézióját is birtokló „új anyagcsoport” jól kezelhető és klinikailag sokféleképpen alkalmazható $[23,25]$. Mivel nem tudnak közvetlenül kötődni a fog keményszöveteihez, ennek megfelelően applikációjuk elött valamilyen primer használata szükséges. A komponensek nagy része a kompozitok összetételéhez hasonlóan nagyméretű monomer, mint például biszfenol A-glicidil metakrilát (bis-GMA) és ennek származékai, az uretán-dimetakrilát (UDMA) és a trietilén-glikoldimetakrilát (TEGDMA). A polimer rendszer non-reaktív anorganikus port (például kvarcot és szilikátüveget) használ töltőanyagként. A töltőanyagok szilánnal borítottak, ami elősegíti a mátrixszal való kötések kialakulását. A kompomerek az iniciális polimerizáció után kis adagokban vizet vesznek fel, ami sav-bázis reakciót indít el az anyag belsejében a reaktív üvegrészecskék és a savas funkciós csoportok között. Ez a folyamat többek között az üvegrészecskékből származó fluorid leadását indukálja a mátrixba, ahonnan a szájba kerülve klinikailag előnyös antikariogén hatást fejt ki [23, 25, 34].

A legtöbb ragasztóanyag megköveteli a zománc kondicionálását a bracketragasztás előtt. Ez történhet hagyományosan ortofoszforsavval, self-etch mechanizmussal, poliakrilsavval, illetve létezik olyan ragasztóanyag is, melynél nem szükséges savat használni (nonetch). 1955-ben Michael G. Buonocore írta le, hogy a felszínt $85 \%$-os foszforsavval kezelve jobb adhéziós erőket ért el akrilát tömőanyag esetében. Azóta már tudjuk, hogy a technikán és a töménységi fokon finomítva, 37\%-os foszforsavval körülbelül 30 másodpercig kondicionálva a zománcot érhetők el a legkedvezőbb feltételek a ragasztóanyag bekötődéséhez. A technika mögött lévő elmélet az, hogy a sav irreverzibilisen kioldja a fogzománc legfelszínesebb ásványi anyag rétegét (nem egyenletes mélységben és mértékben) és felszínnövekedést hoz létre, ami a mikrokötések kialakításánál előnyös tulajdonság [7, 27, 31, 32]. Az önsavazó rendszerek múködése a sav és a primer szerepét kombinálja össze. A primer elsődleges szerepe behatolni a zománc rétegei közé, hogy elősegítse a ragasztóanyag hatékonyabb kötődését a zománchoz. Savas kémhatású primer használata után nem szükséges leöblíteni a zománcot, ami időt spórol az orvosnak és kizárja az íny sav általi esetleges sérülését. Összehasonlítva a hagyományos savazással, több kutatás megerősíti, hogy a self-etch rendszerek kevésbé károsítják a fogzománcot. Az elsőnél ugyanis viszonylag vastag és mélyre hatoló rezin tag-ek képződnek, a második technikánál jóval kevesebb és kisebb tag. A selfetching primerek (SEP) $\mathrm{pH}$-ja lehet magasabb $(\mathrm{pH} 2$ körül) és alacsonyabb (pH 1 körül), de ez látszólag nem befolyásolja a kötőerők nagyságát, tehát valószínüleg érdemes a zománcot jobban kímélő, magasabb pH-jú fajtát alkalmazni $[9,27]$. In vitro vizsgálatok nem találtak szignifikáns különbséget a hagyományos többlépéses eljárás és a SEP-ek kötőerői között [2, 4, 29]. Persze ezek az eredmények csak előrevetítik az anyag klinikai körülmények közötti viselkedését. Az orális környezetet, a többvektorú rágóerőket és az adhezívet a szájban érő egyéb hatásokat nem is lehet teljes mértékben modellezni. A szakirodalomban sok helyen szignifikáns különbséget írnak le a SEP-ek és a konvencionális savazás között az utóbbi javára in vivo, más vizsgálatok pedig hasonló hatékonyságúnak hozzák ki őket [6, 15, $18,24]$.

\section{Vizsgálati módszer}

\section{Szakirodalom kutatás}

A szakirodalmi források gyűjtéséhez használt keresőmotorok a PubMed és a Google Scholar voltak. Fő kritériumunk volt, hogy a beválasztott vizsgálatok mind 
in vivo bracket-leválási rátákat tartalmazzanak. A direkt és indirekt technika összehasonlítására vonatkozóan az alábbi angol keresőszavakat használtuk: clinical comparison of direct and indirect bonding technique, bracket failure rate. Az elemzéskor fontos szempont volt, hogy azonos típusú vizsgálatok kerüljenek beválogatásra (randomizált kontrollált vizsgálatok), valamint az, hogy meghatározzuk az irodalomkutatás időintervallumát. Ez jelen vizsgálatban 1975 és 2019 közé esett. A ragasztóanyagok összehasonlításánál mindegyik anyag tulajdonságairól gyújtöttünk irodalmi adatokat az alábbi keresőszavak alapján: bracket bonding materials, orthodontic adhesives, composite resins, glass ionomer cement, RMGIC, compomer. A továbbiakban a leválási rátákra koncentráltan in vivo összehasonlító vizsgálatokra kerestünk: clinical comparison of bracket failure rates with glass ionomer, RMGIC, composite resin, compomer. Harmadik szempontunk a zománc előkészítése volt. Ebben az esetben szintén szakirodalmi tájékozódás után az alábbi keresőszavakat használtuk: conventional acid etching, self-etching primers, bracket bond strength, acid-etch bonding system, bonding to enamel.

\section{Saját vizsgálat}

Saját vizsgálatunkat a Fogászati és Szájsebészeti Oktató Intézet Fogszabályozási Osztályán kezelt páciensekről szóló adatokra alapoztuk. A bracket ragasztás minden esetben azonos módon történt, direkt eljárással. A fogakat először fluormentes pasztával alaposan megtisztították, leszárították majd relatívan izolálták. Ezt követően $36 \%$-os ortofoszforsavval kondicionálták a zománcot 30-40 másodpercig, majd alaposan leöblítették és megszárították a felszínt. A kondicionálásra használt termék a Blue Etch (Cerkamed, Stalowa Wola, Poland) gél állagú sav volt. Következő lépésként a matt felszínre Ortho Solo (Ormco, Sturtevant, Wisconsin, USA) nevű primert vittek fel. Utolsó lépésként a bracketek talpára helyezték a ragasztót és pozicionálták, majd a kifolyt felesleg eltávolítása után LED polimerizációs lámpával 410-490 nm-es hullámhossztartományba eső fénynyel megvilágították őket. A használt ragasztóanyag a Transbond XT (3M ${ }^{\mathrm{TM}}$, St. Paul, MN, USA) volt. Ez egy fényrekötő kompozit rezin alapú adhezív, ami probléma nélkül képes egyaránt fém és kerámia bracketekhez is kötődni.

\section{Eredmények}

\section{Direkt és indirekt technika}

Zacharisson és Brobakken 1978-ban 42 gyermeken összesen 444 bracket és tubus felragasztásának kimenetelét vizsgálták. A bracket-leválások száma megállapításuk szerint alacsonynak mondható, különösen a direkt módon ragasztottak esetében. Direkt módszerrel 243 bracketből/tubusból 6 vált le $(2,5 \%)$, indirekt módszerrel pedig 201-ből 28 darab (13,9\%). A különbség statisztikailag szignifikánsnak minősül [38].

Egy másik, 1982-ben végzett vizsgálatban 3 hónappal a bracketek felragasztása után az alábbi leválási ráták adódtak: 4,5\% az indirekt technikát és 5,3\% a direkt technikát alkalmazva. A két adat között nem szignifikáns a különbség [1].

32 fő bevonásával készült 2006-ban egy in vivo vizsgálat, melynek során 1 éven keresztül regisztrálták a bracket-leválásokat. Összesen 539 bracket sorsát követték nyomon, amelyből $14 \mathrm{db}$ vált le a vizsgált időtartamban. Statisztikai analízis nem mutatott szignifikanciát a direkt és indirekt módszer között [35]. (1. táblázat)

Egy 2013-as vizsgálat nem talált jelentős különbséget a két technika között, bár nagyobb leválási számokat regisztráltak az indirekt ragasztásos esetekben. Az eredeti cél a direct bracket bonding (DBB) és indirect bracket bonding (IBB) által igényelt idő összehasonlítása volt, mellékes adatként regisztrálták a bracketleválási számot is. 17 páciens összesen 304 felragasztott bracketjét foglalta magába a vizsgálat, amiből 151 direkt és 153 pedig indirekt technikával került rögzítésre. Mindkét csoportban azonos bracketeket és ragasztókat használtak a jobb összehasonlíthatóság kedvéért és 24 hétig követték nyomon a bracketek sorsát. A két technika bracket-leválási arányai között tehát nem mutatkozott szignifikáns különbség [5]. (1. táblázat)

Bracket-leválási adatok és százalékok

\begin{tabular}{|l|l|c|c|c|}
\hline Szerző & Csoportok & Felragasztott bracketek & Levált bracketek & Százalékos arány \\
\hline \multirow{3}{*}{ S. Thiyagarajah, et al [35] } & Direkt & 266 & 8 & $2,9 \%$ \\
\cline { 2 - 5 } & Indirekt & 273 & 6 & $2,2 \%$ \\
\cline { 2 - 5 } & Össz. bracketszám & 539 & 14 & $2,5 \%$ \\
\hline \multirow{3}{*}{ J. V. Bozelli I., et al [5] } & Direkt & 151 & 7 & $4,6 \%$ \\
\cline { 2 - 5 } & Indirekt & 153 & 11 & $7,2 \%$ \\
\cline { 2 - 5 } & Össz. bracketszám & 304 & 18 & $5,9 \%$ \\
\hline \multirow{3}{*}{ A. Menini, et al [20] } & Direkt & 792 & 28 & $3,5 \%$ \\
\cline { 2 - 5 } & Indirekt & 456 & 26 & $5,7 \%$ \\
\cline { 2 - 5 } & Össz. bracketszám & 1248 & 54 & $4,3 \%$ \\
\hline
\end{tabular}


Egy 2014-es longitudinális klinikai vizsgálat is foglalkozott az indirekt ragasztás hatékonyságával. Az összes elemzett bracketszám 1248 volt (792 direkt és 456 indirekt). A leválási rátát és egyéb adatokat 15 hónapon keresztül regisztrálták. A kiértékelt eredmények nem mutattak szignifikáns különbséget a két csoport között, kivéve az alsó állcsont posterior régiójában. Vizsgálták a fogtorlódás fokának összefüggését a bracket-leválásokkal kapcsolatosan, de itt nem mutatkozott szignifikáns eltérés. Összefoglalva tehát a tanulmány álláspontját, a direkt és indirekt módszer is biztonságosan és eredményesen használható, akár erősen torlódott fogazat esetében is, mivel ez a faktor nem befolyásolja a kötés minőségét, illetve a bracketek túlélését [20]. (1. táblázat)

\section{Anyagok szerinti leválási ráták}

Egy 12 hónapon keresztül végzett vizsgálat kiugróan magas leválási számokat regisztrált az üvegionomerek esetén $(50,9 \%)$, míg kompozittal ragasztott bracketek csupán $8 \%$-a vált le [21]. Egy másik, ugyanilyen időtartamú klinikai mérés szintén szignifikáns különbséget tárt fel a két anyag kapcsán (üvegionomer: $20 \%$, kompozit: $5 \%$ ) [11].

1998-ban készült in vivo vizsgálat során RMGIC leválási rátáit (Fuji Ortho LC, GC, Alsip, USA) hasonlították össze kémiailag kötő kompozittal (Orthodontic Concise, $3 \mathrm{M}^{\mathrm{TM}}$, St. Paul, MN, USA) és 12 hónapon keresztül követték a bracketeket. Az első esetben $6 \%$-os, a második esetben pedig 5,4\%-os leválási arányt jegyeztek fel (a különbség nem volt szignifikáns) [10].

1999-ben készült egy olyan komplexebb felmérés, ami a bracket-leválási arányok mellett a RMGIC (Fuji Ortho LC) fluorid leadását is vizsgálta, a klinikailag a bracketek körül észlelhető demineralizáció mértéke alapján. Kontrollként fényrekötő kompozit rezin adhezív szolgált (Reliance Light Bond). Az üvegionomer típusú ragasztót a gyártó utasításainak megfelelően, a zománc bárminemú savas kezelése nélkül használták. A pácienseket 12-14 hónapig tartó időkeretben követték, minden fog bracket-leválását feljegyezték, illetve a felső állcsont frontfogain az újonnan keletkező fehér foltokat egy skálán értékelték. A leválási ráták a következők: RMGIC $24,8 \%$, kompozit rezin 7,4\%. A dekalcifikáció kapcsán a két csoportban hasonló eredményekre jutottak (nincs szignifikáns különbség). A vizsgálatból levonható következtetés, hogy a RMGIC-ek zománc kondicionálás nélküli használata szignifikánsan alacsonyabb kötőeröket eredményez a kompozit rezinekhez képest [12].

2001-ben került sor egy 18 hónapon át tartó vizsgálatra, amely szintén a RMGIC klinikai viselkedésére fókuszált. A 135 páciens részvételével végzett, két (azonos technikát alkalmazó) szakorvos ténykedését elemző kutatás során 6113 Fuji Ortho LC (GC, Alsip, USA) ragasztóval felhelyezett bracketet követtek nyomon. Az össz leválási ráta 7\%-os volt, ami a kompozittal foglalkozó irodalmi adatoknak megfelelő. Következtetésképp, a megfelelő protokollt követve (nyálmentes száraz felszínen, poliakrilsavas kondicionálással) az anyag klinikailag adekvátnak bizonyult [13].

Kompozitot (Right-On, GC, Morley, UK) és kompomert (Dyract Ortho, Dentisply Sirona, USA) hasonlítottak össze egy 2000 -es vizsgálat során. A leválási ráta a kompomerrel való ragasztás során $17 \%$, míg a kompozittal történő ragasztás során $20 \%$ volt, ami nem számított szignifikáns különbségnek. A magas százalékok valószínúleg a felhasznált bracket típusának és kis retenciós felületének (Mini-Twin 3M Unitek, St. Paul, USA) voltak köszönhetők, mellyel kapcsolatban az irodalomban nagyobb leválási számokat jeleztek, mint a hagyományos méretű bracketek esetében. A kompomerek az üvegionomereknél kisebb mértékben, de képesek fluorid felvételére és leadására. Ezt támasztja alá, hogy a rezin adhezívvel ragasztott bracketek körül átlagosan több dekalcifikációs területet figyeltek meg (kompomer: 20\%, kompozit: 26\%). Ez szignifikánsnak minősül, ami a kompomerek karioprotektív hatása mellett szól [23].

Egy 2003-as randomizált klinikai vizsgálat két új, nedvességre rezisztens adhezív összevetését tǔzte ki célul, az egyik egy kémiailag kötő kompozit (Unitek, 3M St. Paul, USA \& MIP, 3M St. Paul, USA), míg a másik fluorid leadására képes fényrekötő kompomer (Assure, Reliance Orthodontic Products, Chicago, USA). A 9 hónapon keresztül végzett vizsgálat során feljegyezték a leválási rátákat és felvették a hozzájuk tartozó ARI indexet (a bracket leválása/eltávolítása után a fogon maradt ragasztóanyag mennyiségét figyelembe vevő skála, amit Årtun és Bergland írtak le 1984-ben). A kompomer 13,8\%-os leválási rátája szignifikánsan nagyobb a másik anyag 7,3\%-os teljesítményéhez képest $(P<$ $0,05)$. Mindkét esetben a hiba többsége kohéziós típusú volt, azaz a ragasztóanyagon belül történt meg az elválás. Az ARI értékek alapján a kompomerrel ragasztott bracketek leválásánál gyakrabban fordult elő, hogy az összes ragasztó a fogon maradt, vagyis potenciálisan gyengébb kötés jön létre az adhezív-bracketfelületen $[19,30]$.

\section{Hagyományos kondicionálás \\ és self-etch mechanizmus}

2003-ban 6 hónapos időtartamon keresztül vizsgálták SEP-rel és hagyományos rendszerrel felragasztott precoated (ragasztóval elöre bevont) bracketek klinikai viselkedését. SEP-rel a bracketek $11 \%$-a, foszforsavas savazással pedig $5 \%$-a vált le a fogról (szignifikáns a különbség) [15].

Egy 2006-os, 12 hónapon átívelő klinikai vizsgálat szerint statisztikailag jelentősen gyengébb a SEP-ek teljesítménye (SEP: $11,2 \%$, konvencionális: $3,9 \%, P=$ $0,001)$. A SEP-nél többségében a zománc-adhezív határon következett be a leválás (alacsony ARI szám), míg a konvencionálisnál az anyagon belül (magasabb ARI szám). Korábbi vizsgálatok szerint a premoláris fogak szintjén találhatók a legmagasabb leválási ráták, 
valószínűleg a nagyobb rágóerőknek, a nehezebb izolációnak és a nagyobb mennyiségú aprizmatikus zománcállománynak köszönhetően. Ebben a vizsgálatban a felső premolárisokról vált le a legtöbb bracket, ami egyezik a szakirodalom megállapításaival [24].

Egy másik 2006-os tanulmány a kezelés első 6 hónapjában az alábbi eredményeket publikálta: SEP: 1,7\%, konvencionális: $2,0 \%$. A kezelés teljes időtartamára vonatkozóan pedig: SEP: $7 \%$, konvencionális $7,4 \%$, egyik esetben sem volt szignifikáns a különbség. Az orvossal, a pácienssel és a foggal kapcsolatban, csak az utóbbira volt szignifikáns az eredmény. A felső fogsorról több bracket vált le, itt körülbelül ötszörös a rizikó, aminek pontos oka nem ismert, de különböző rossz szokások, például a körömrágás, tollrágcsálás szerepét feltételezik. A cikk szerint mindkét adhezív alkalmas és ajánlott klinikai használatra [18].

2009-ben egy másik, az előzőekhez nagyon hasonló struktúrájú kutatást végeztek, amelyben összesen 548 bracket sorsát követték. A hagyományos eljárással ragasztott bracketek 4,8\%-a, míg az önsavazó rendszerrel $6,9 \%$ vált le a hordás során. A kettő között nincs szignifikáns különbség $(P=0,311)$. A fogtípust, az állcsontot és a nemet figyelembe véve egyedül az első esetben volt szignifikáns az eltérés (a hátsóbb régiókban volt a legtöbb bracket-leválás). Mindkét rendszer klinikailag adekvátnak bizonyult [6].

\section{Saját vizsgálat eredményei}

A Fogászati és Szájsebészeti Oktató Intézet Fogszabályzási Osztályának rögzített készülék rendelési nyilvántartása alapján pontosan tudjuk, hogy hány multibond készülék (azaz hány darab bracket) került megrendelésre, illetve utánrendelésre az általunk követett időtartamban, 2019. január 1 . és október 4 . között. A bracketeket a páciensek számára egyénenként recepten rendelik meg és ragasztják fel. Ennek alapján, az utánrendelési számot a megrendelési számmal elosztva kapjuk meg a bracket-leválási arányt. A bracketeket rendszerint a leválásuk miatt rendelik újra, azaz az utánrendelési számok jó közelítéssel megegyeznek a leválási számokkal. A leesett bracketet nem ragasztják vissza, tehát ez a jelenség nem szerepel befolyásoló tényezőként az adatokat illetően. Az adatokat az a ritka eset módosíthatja, amikor a szakorvos távolít el egy bracketet (például újrapozicionálás céljából) és újat rendel.

Adataink alapján a legnagyobb számban felhasznált és emiatt legpontosabban nyilvántartott Omni típusú fémbracketek leválási rátáira tudtunk következtetni. (2. táblázat) A vizsgált időtartamban összesen 64 darab Omni bracketet rendeltek után, feltételezhetően a leválásuk miatt. Az összes felragasztott Omni bracketszám pedig 1570 darab. Az utánrendelés aránya a teljes ren- deléshez képest - ami számunkra a valószínűsíthető leválási ráta $-4,1 \%$-nak adódik. Ilyen nagy mintaszám mellett a kapott érték jó közelítést nyújt a bracketek tényleges leválási számához.

2. táblázat

Bracket megrendelési és utánrendelési adatok

\begin{tabular}{|c|c|c|c|}
\hline Típus & Megrendelés & Utánrendelés & Leválási ráta \\
\hline $\begin{array}{c}\text { Omni } \\
\left(0,18^{\prime \prime}\right.\end{array}$ & $1570 \mathrm{db}$ & $64 \mathrm{db}$ & $4,1 \%$ \\
és $\left.0,22^{\prime \prime}\right)$ & & & \\
\hline
\end{tabular}

\section{Megbeszélés}

A direkt és indirekt technika tekintetében általánosan azt mondhatjuk, hogy a feldolgozott források alapján nincs szignifikáns különbség a leválási ráták tekintetében. (1. ábra) Látható, hogy mind direkt, mind indirekt technikával az irodalmilag elfogadott $10 \%$-os leválási ráta alatt tudtak maradni. Kivételt képez az 1978-as vizsgálat, ahol az indirekt technika meghaladja ezt a számot. Ennek magyarázata többek között az akkori indirekt ragasztás fejletlensége lehet $[1,5,20,35,38]$. A kezelőorvos egyéni preferenciáinak (pl. ragasztásra szánt székidő) és a rendelő lehetőségeinek megfelelően érdemes kiválasztani az optimális módszert.

Következő szempontunk az anyagok szerinti összehasonlítás volt. Az üvegionomer cementek a beválogatott vizsgálatokban a kompozitokhoz képest szignifikánsan nagyobb leválási számokat mutattak. (2. ábra) A RMGIC-ek fejlődését nyomon követve egyre inkább a kompozitok alternatívájaként lehet rájuk tekinteni, amit a kompozitokhoz hasonló leválási számok támasztanak alá. A bracket adhezívként a közelmúltban felbukkanó kompomerek szintén megközelítik a kompozitok kötőerejét. A legnagyobb kötőerőket a kompozitok képesek kialakítani a fogzománccal, ennek megfelelőan a legalacsonyabb leválási számokat itt láthatjuk. A mai napig ezek a legelterjedtebben használt bracketragasztó anyagok [19].

Harmadik szempontunk a zománc előkészítése a bracket-ragasztás előtt. (3. ábra) Két vizsgálatban a SEP-t használó ragasztásnál a bracket leválásiszámok meghaladják a szakirodalomban elfogadottnak számító $10 \%$-os értéket és szignifikánsan gyengébben szerepelnek a hagyományos eljáráshoz képest. A többlépéses kondicionálási eljárás következtében magasabb kötőerők képesek kialakulni és kevesebb bracket válik le, emiatt általánosan elmondható, hogy a ragasztást egyszerüsítő önsavazó primerek a hagyományos eljáráshoz képest kevésbé megbízhatóak a bracketleválási rátát figyelembe véve. 


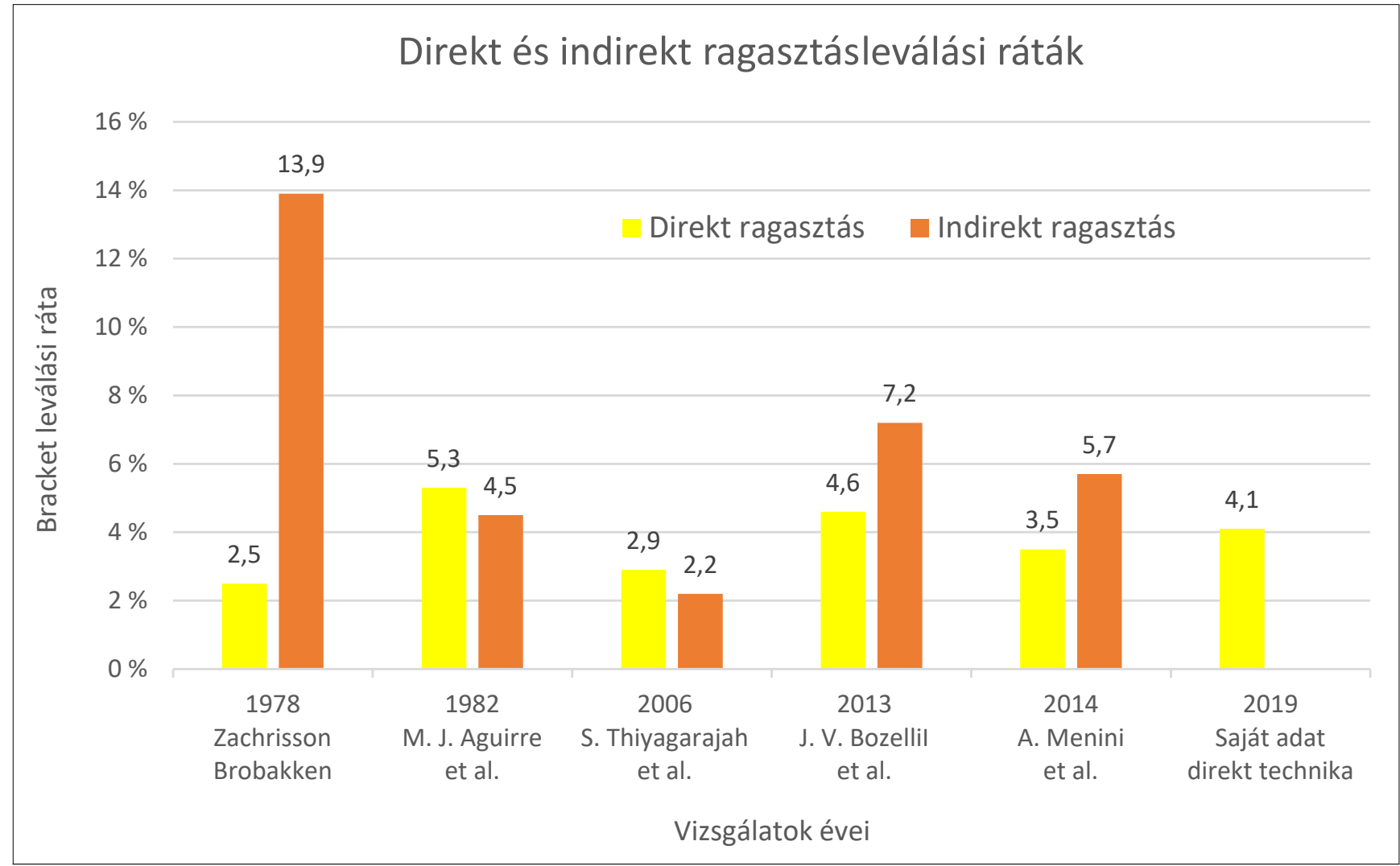

1. ábra: Direkt és indirekt ragasztásleválási ráták

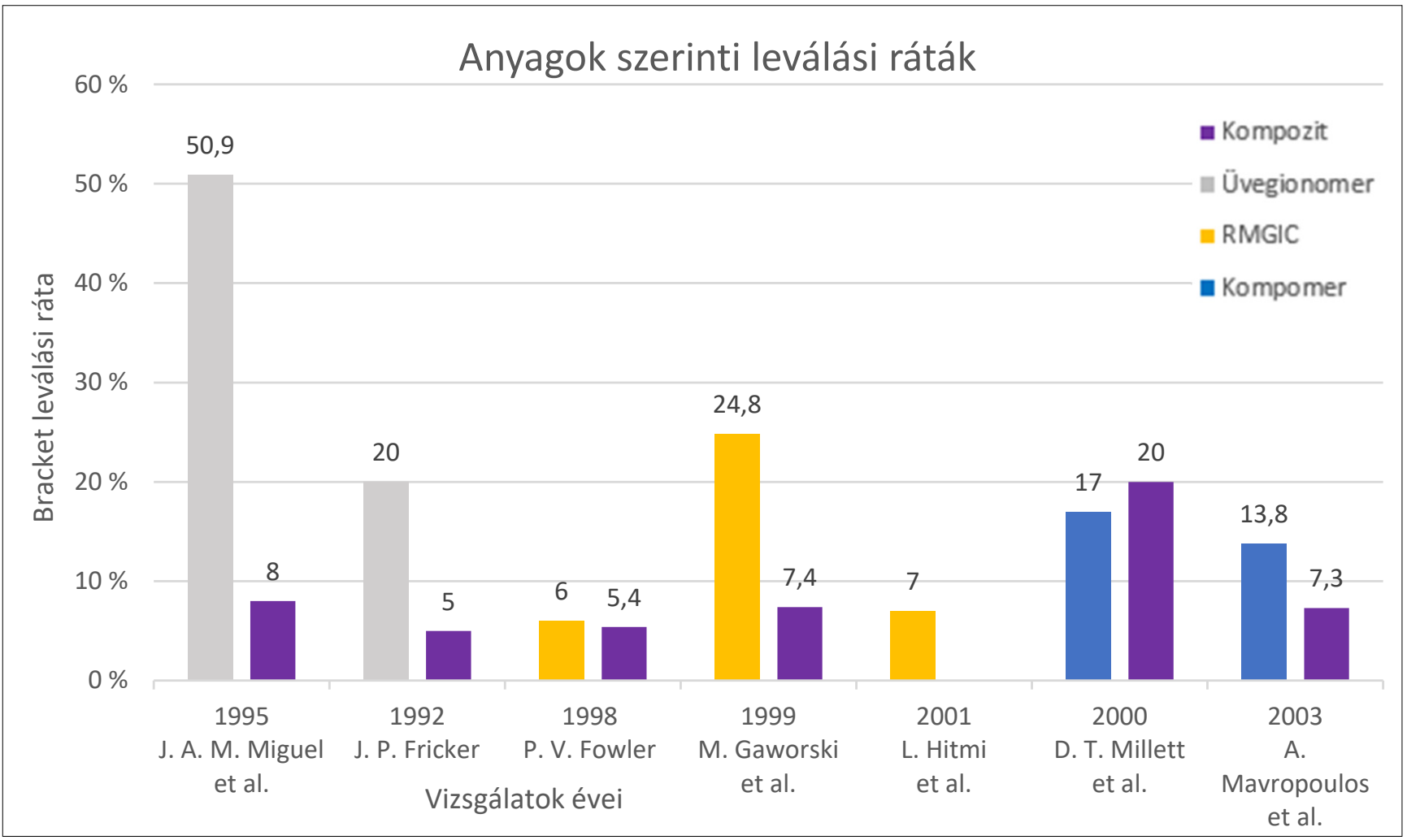




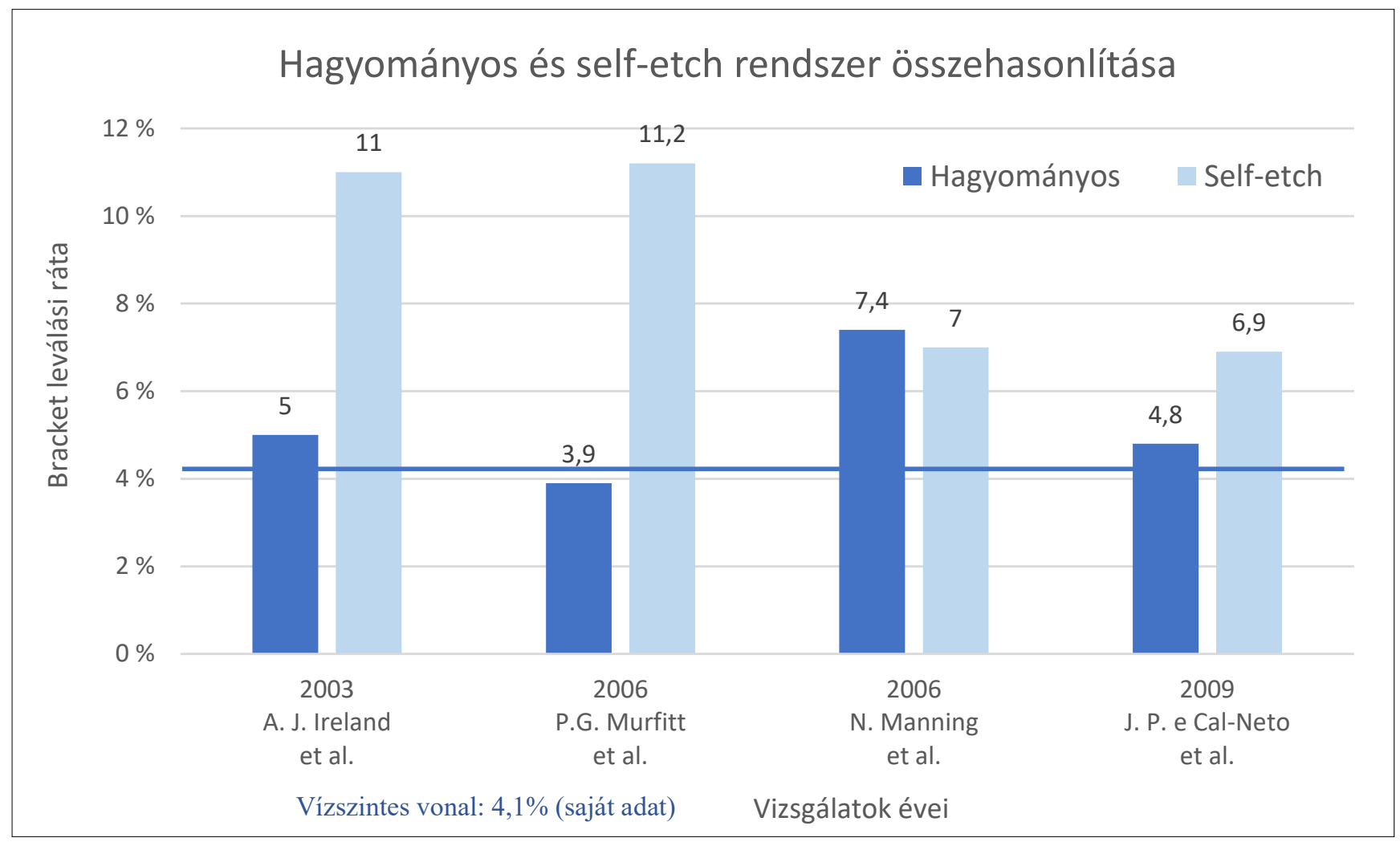

3. ábra: Hagyományos és self-etch rendszer összehasonlító rátái

\section{Összefoglalás}

Az egyes bracketragasztási technikák sikerességéről in vivo a bracketleválási ráta ad adekvát információt. Összehasonlításunk szerint mind a direkt, mind az indirekt bracketragasztás megfelelően alkalmazható metódus. A bracketragasztáskor a legnagyobb kötőerő a kompozit rezinek használatakor keletkezik. A self-etch rendszerek használata során nagyobbnak bizonyul a bracketek leválási aránya, mint a hagyományos totaletch rendszerek alkalmazásakor. A Fogászati és Szájsebészeti Oktató Intézetben alkalmazott ragasztási technika megbízhatóságát támasztja alá a 4,1\%-os leválási ráta. A multibond készülékek kiküszöbölhetetlen velejárója a bracketleválás. Az orthodontus feladata, hogy ezt minél alacsonyabb szintre szorítsa. Ezzel párhuzamosan folyamatosan monitoroznia kell saját, illetve működési egységének, osztályának bracketleválási rátáját, hogy ezzel is javítson a minőségbiztosítási (quality assurance) és a minőségellenőrzési (quality control) mutatókon.

\section{Irodalom}

1. Aguirre Michael J, King Gregory J, Waldron Joseph M: Assessment of bracket placement and bond strength when comparing direct bonding to indirect bonding techniques. American Journal of Orthodontics 1982, Volume 82, Number 4, Pg. 269-276. https:// doi.org/10.1016/0002-9416(82)90461-4
2. Arnold Ryan W, Combe Edward C, Jr John H Warford: Bonding of stainless steel brackets to enamel with a new self-etching primer. American Journal of Orthodontics and Dentofacial Orthopedics 2002, Volume 122, Issue 3, September 2002, 274-276. https://doi. org $/ 10.1067 / \bmod .2002 .125712$

3. Benson Philip E, Alexander-Abt Jonathan, Cotter Stephen, Dyer Fiona MV, Fenesha Fatma, Patel Anjli: Resin-modified glass ionomer cement vs composite for orthodontic bonding: A multicenter, single-blind, randomized controlled trial. American Journal of Orthodontics and Dentofacial Orthopedics 2019, Volume 155, Issue 1, 10-18. https://doi.org/10.1016/j.ajodo.2018.09.005

4. Bishara Samir E, Ajlouni Raed, Laffoon John F, Warren John J: Effect of a Fluoride-Releasing Self-Etch Acidic Primer on the Shear Bond Strength of Orthodontic Brackets. The Angle Orthodontist June 2002; Vol. 72, No. 3, 199-202.

5. Bozelli Jefferson Vinicius, Bigliazzil Renato, Barbosail Helga Adach Medeiros, Ortolanilil Cristina Lucia Feijo, Bertoziv Francisco AntoNIO, JUNIOR KURT FALTIN: Comparative study on direct and indirect bracket bonding techniques regarding time length and bracket detachment. Dental Press Journal of Orthodontics 2013, Vol. 18. no. 6. https://doi.org/10.1590/S2176-94512013000600009

6. Cal-Neto Julio Pedra E, Quintão Cátia Abdo, Almeida Marco Antôniode Oliveira, Miguel José Augusto Mendes: Bond failure rates with a self-etching primer: A randomized controlled trial. American Journal of Orthodontics and Dentofacial Orthopedics 2009, Volume 135, Issue 6, June 2009, 782-786. https://doi.org/10.1016/j.ajodo.2008. 11.022

7. Feizbakhsh Masoud, Aslani Farzin, Gharizadeh Naghme, Heidarizadeh MostABA: Comparison of bracket bond strength to etched and unetched enamel under dry and wet conditions using Fuji Ortho LC glass-ionomer. J Dent Res Dent Clin Dent Prospects 2017, 11(1): 30-35. https://doi.org/10.15171/joddd.2017.006

8. FerRacAne JaCk L: Resin composite-State of the art. Dental Materials 2001, (1): 29-38. https://doi.org/10.1016/j.dental.2010.10.020 
9. FJeld Morten, Øgaard Bjørn: Scanning electron microscopic evaluation of enamel surfaces exposed to 3 orthodontic bonding systems. American Journal of Orthodontics and Dentofacial Orthopedics 2006, Volume 130, Issue 5, November 2006, 575-581. https://doi.org/10.1016/j.ajodo.2006.07.002

10. FOWLER PV: A twelve-month clinical trial comparing the bracket failure rates of light-cured resin-modified glass-ionomer adhesive and acid-etch chemical-cured composite. Australian Orthodontic Journal 1998, Vol. 15, No. 3, Oct 1998: 186-190.

11. FRICKER JP: A 12-month clinical evaluation of a glass polyalkenoate cement for the direct bonding of orthodontic brackets. American Journal of Orthodontic and Dentofacial Orthopedics 1992, Volume 101, Issue 4, 381-384. https://doi.org/10.1016/ S0889-5406(05)80332-4

12. Gaworski Matthew, Weinstein Martin, Borislow Alan J, Braitman LEONARD E: Decalcification and bond failure: A comparison of a glass ionomer and a composite resin bonding system in vivo. American Journal of Orthodontics and Dentofacial Orthopedics 1999, Volume 116, Issue 5, November 1999, 518-521. https:// doi.org/10.1016/S0889-5406(99)70182-4

13. Hitmi Laïla, Muller Christine, Mujajic Magali, Attal Jean-Pierre: An 18-month clinical study of bond failures with resin-modified glass ionomer cement in orthodontic practice. American Journal of Orthodontics and Dentofacial Orthopedics 2001, Volume 120, Issue 4 October 2001, 406-415. https://doi.org/10.1067/mod.2001.115931

14. Hodge TM, Dhopatkar AA, Rock WP, Spary DJ: A Randomized Clinical Trial Comparing the Accuracy of Direct versus Indirect Bracket Placement. Journal of Orthodontics 2004, Volume: 31 issue: 2, page(s): 132-137. https://doi.org/10.1179/ 146531204225020427

15. Ireland Anthony J, Knight Helen, Sherriff Martyn: An in vivo investigation into bond failure rates with a new self-etching primer system. American Journal of Orthodontics and Dentofacial Orthopedics 2003, Volume 124, Issue 3, September 2003, 323-326. https://doi.org/10.1016/S0889-5406(03)00403-7

16. Komori AKIRA, Ishikawa HaRUo: Evaluation of a resin-reinforced glass ionomer cement for use as an orthodontic bonding agent The Angle Orthodontist 1997, Vol. 67, No. 3: 189-196.

17. MalJer R, Smith DC: A compatison between zinc phosphate and glass ionomer cement in orthodontics. American Journal of Orthodontics and Dentofacial Orthopedics 1999, Volume 93 Number 4, 273-279. https://doi.org/10.1016/0889-5406(88)90156-4

18. Manning N, Chadwick SM, Plunkett D, Macfarlane TV: A randomized clinical trial comparing 'one-step' and 'two-step' orthodontic bonding systems. Journal of Orthodontics 2006; 33: 4, 276-283. https://doi.org/10.1179/146531205225021825

19. Mavropoulos A, Karamouzos A, Kolokithas G, Athanasiou AE: In Vivo Evaluation of Two New Moisture-Resistant Orthodontic Adhesive Systems: A Comparative Clinical Trial. Journal of Orthodontics 2003, Volume: 30 issue: 2, page(s): 139-147. https://doi. org/10.1093/ortho/30.2.139

20. Menini A, CozZani M, Sfondrini MF, AL. ET: A 15-month evaluation of bond failures of orthodontic brackets bonded with direct versus indirect bonding technique: a clinical trial. Progress in Orthodontics 2014, 15., 70. https://doi.org/10.1186/s40510-014-0070-9

21. Miguel Jose Augusto Mendes, Almeida Marco Antonio, ChevitaRESE ORLANDO: Clinical comparison between a glass ionomer cement and a composite for direct bonding of orthodontic brackets. American Journal of Orthodontics and Dentofacial Orthopedics 1995, Volume 107, Issue 5, May 1995, 484-487. https://doi.org/ 10.1016/S0889-5406(95)70115-X

22. Millett DT, Mccabe JF: Orthodontic bonding with glass ionomer cement-a review. European Journal of Orthodontics 1996, 18 (4) 385-399. https://doi.org/10.1093/ejo/18.4.385
23. Millett DT, Mccluskey LA, Mcauley F, Creanor Sl, Newell J, Love J: A Comparative Clinical Trial of a Compomer and a Resin Adhesive for Orthodontic Bonding. Angle Orthodontist 2000, Vol 70, No 3, 2000.

24. Murfitt PG, Quick AN, Swain MV, Herbison GP: A randomised clinical trial to investigate bond failure rates using a self-etching primer. European Journal of Orthodontics 2006, Volume 28 Issue 5, October 2006, 444-449. https://doi.org/10.1093/ejo/ cjl007

25. Nicholson John W: Polyacid-modified composite resins ("compomers"). Dental Materials 2007, 23 (2007) 615-622. https://doi. org/10.1016/j.dental.2006.05.002

26. Nojima lincoln Issamu, Araújo Adriele Silveira, Alves Matheus, JÚNIOR: Indirect orthodontic bonding - a modified technique for improved efficiency and precision. Dental Press J Orthod 2015, May-Jun; 20 (3): 109-117. https://doi.org/10.1590/2176-9451.20. 3.109-117.sar

27. Øgaard Buørn, FJeld Morten: The Enamel Surface and Bonding in Orthodontics. Seminars in Orthodontics 2010, Volume 16, Issue 1, March 2010, 37-48. https://doi.org/10.1053/j.sodo.2009. 12.003

28. RAHIOTIS C, SCHRICKER S: Bonding with glass ionomer cements and resin-modified glass ionomer cements. Orthodontic Applications of Biomaterials 2017, 253-265. https://doi.org/10.1016/ B978-0-08-100383-1.00016-3

29. Rajagopal Rangaswamy, Padmanabhan Sridevi, Gnanamani JanaKIRAMA: A Comparison of Shear Bond Strength and Debonding Characteristics of Conventional, Moisture-Insensitive, and Selfetching Primers In Vitro. The Angle Orthodontist 2004, Vol. 74, No. 2, 264-268.

30. Regan D, Lemasney B, Noort R van: The tensile bond strength of new and rebonded stainless steel orthodontic brackets. European Journal of Orthodontics 1993, Volume 15, Issue 2, April 1993, 125-135. https://doi.org/10.1093/ejo/15.2.125

31. ReYNolds IR: A Review of Direct Orthodontic Bonding. British Journal of Orthodontics 1975; 2: 3, 171-178. https://doi.org/10. 1080/0301228X.1975.11743666

32. Rossouw P EmILE: A Historical Overview of the Development of the Acid-Etch Bonding System in Orthodontics. Seminars in Orthodontics 2010, Volume 16, Issue 1, March 2010, 2-23. https:// doi.org/10.1053/j.sodo.2009.12.002

33. Swift Edward, Perdigao Jorge, Heymann H: Bonding to enamel and dentin: a brief history and state of the art, 1995. Quintessence international (Berlin, Germany: 1985) 1995; 26: 95-110.

34. Tate WH, You C, Powers JM: Bond Strength of Compomers to Human Enamel. Operative Dentistry 2000, 25, 283-291.

35. Thiyagarajah S, Spary DJ, Rock WP: A clinical comparison of bracket bond failures in association with direct and indirect bonding. Journal of Orthodontics 2006, Vol. 33, 198-204. https://doi. org/10.1179/146531205225021615

36. Valente Rudolfo M, RiJk Waldemar G de, Drummond James L, Evans CARLA A: Etching conditions for resin-modified glass ionomer cement for orthodontic brackets. American Journal of Orthodontics and Dentofacial Orthopedics 2002, Volume 121, Issue 5, May 2002, 516-520. https://doi.org/10.1067/mod.2002.122165

37. Y, GIA K, Dunn WiLLIAM J, TALOUMIS LouIS J: Shear bond strength comparison between direct and indirect bonded orthodontic brackets. American Journal of Orthodontics and Dentofacial Orthopedics 2003, Volume 124, Issue 5, November 2003, 577-581. https://doi.org/10.1016/S0889-5406(03)00503-1

38. ZACHRISSON BJÖRN U, BROBAKKEN BJöRN O: Clinical comparison of direct versus indirect bonding with different bracket types and adhesives. American Journal of Orthodontics 1978; Volume 74 Issue 1, 62-78. https://doi.org/10.1016/0002-9416(78)90046-5 


\title{
Original article
}

\author{
SVIDRÓ E, IVÁNYI D, HORVÁTH J
}

\section{Comparing orthodontic bracket bonding methods based on bracket failure rates}

During modern orthodontic treatment brackets are usually placed directly on the tooth enamel. The bond has to withstand a variety of forces (occlusial, masticatory, as well as forces from the wire itself) in the moist oral environment. Additionally, it's important that the bracket leaves behind an intact enamel surface after removal. The quality of the bracket bonding depends mostly on the chosen technique. Our study goal was to compare and evaluate the different bonding methods based on bracket failure rates. PubMed and Google Scholar were used as search engine. We compared recent publications taking three main factors into consideration: direct or indirect bonding technique, bracket bonding materials and the type of etching on the enamel surface (conventional acid etching versus self-etching primers). Additionally, data were collected based on the orders of primary bonded brackets and the order of brackets that needed replacement. over a 10 month period in the Department of Community Dentistry. We used the direct bonding technique, composite resin as bonding material and conventional acid etching in order to achieve micromechanical retention. In our observations the failure rate resulted in $4,1 \%$., which is below the internationally accepted $10 \%$ ratio. [6, 24]

In conclusion no significant differences between direct and indirect bonding techniques were found. Both can provide reliable bonding forces during the whole treatment. Regarding the optimal bonding material, the composite resins are the most widespread and have the highest bonding strengths. Their failure rates are between 3,5-8,3\%. [19] Glass ionomer cements are no longer commonly used as orthodontic bonding material unlike their improved versions: resin-modified glass ionomers (RMGIC). Many studies report favorable results about this relatively new type of bonding material. Compomers are not commonly used as bonding material yet. According to in vitro studies there is no significant difference in failure rates between conventional acid etching and self-etching primers. [2, 4, 29] In several studies were found that larger bonding forces can form with conventional acid etching in vivo. Self-etching primers have the advantage of sparing a lot of chair time for the doctor, causing a positive financial effect too.

Keywords: orthodontics, orthodontic bracket, bracket bonding material, failure rate 